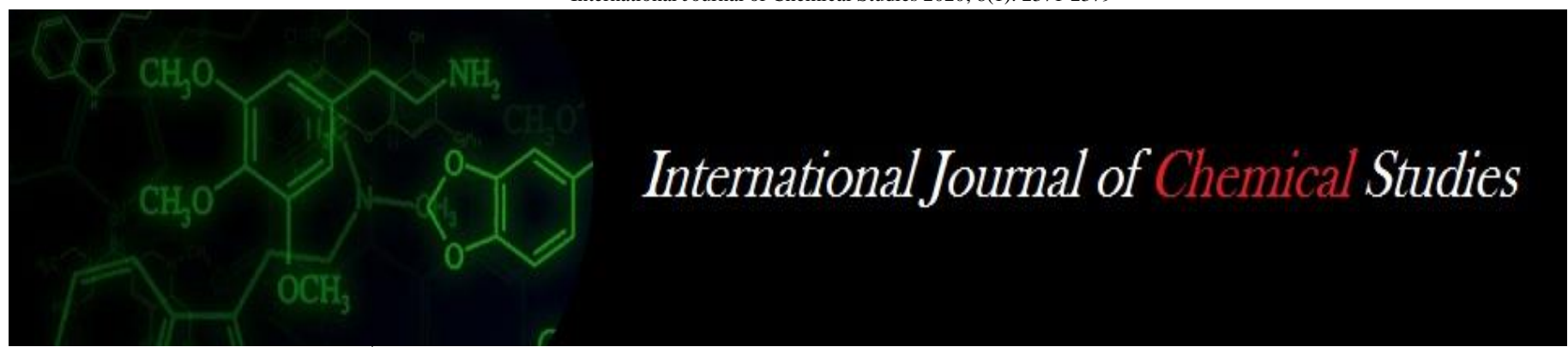

P-ISSN: 2349-8528

E-ISSN: 2321-4902

IJCS 2020; 8(1): 2371-2379

(C) 2020 IJCS

Received: 13-11-2019

Accepted: 15-12-2019

Thounaojam Thomas Meetei (1) ICAR Research Complex for NEH Region, Umiam,

Meghalaya, India

(2) School of Natural Resources

Management, CPGS, CAU,

Umiam, Meghalaya, India

(3) School of Agriculture, Lovely Professional University, Punjab, India

Burhan U Choudhury

ICAR Research Complex for

NEH Region, Umiam,

Meghalaya, India

Kamal P Mohapatra

ICAR Research Complex for

NEH Region, Umiam,

Meghalaya, India

N Uttam Singh

ICAR Research Complex for

NEH Region, Umiam,

Meghalaya, India

Anup Das

ICAR Research Complex for

NEH Region, Umiam,

Meghalaya, India

Yumnam Bijilaxmi Devi

Department of Natural Resource

Management, Rani Lakshmi Bai,

Central Agricultural University,

Jhansi, Uttar Pradesh, India

Corresponding Author:

Thounaojam Thomas Meetei

(1) ICAR Research Complex for

NEH Region, Umiam,

Meghalaya, India

(2) School of Natural Resources

Management, CPGS, CAU,

Umiam, Meghalaya, India

(3) School of Agriculture, Lovely

Professional University, Punjab,

India

\title{
Effect of 25 years old agroforestry practices on soil quality attributes in the north eastern Himalayan region of India
}

\section{Thounaojam Thomas Meetei, Burhan U Choudhury, Kamal P Mohapatra, N Uttam Singh, Anup Das and Yumnam Bijilaxmi Devi}

DOI: https://doi.org/10.22271/chemi.2020.v8.i1aj.8623

\begin{abstract}
Long term effects of six agroforestry practices (AFPs) (>25 years old), on soil attributes with respect to soil degradation and improvement was assessed in the North Eastern Hill region of India and their effectiveness in improving soil health parameters was compared with shifting cultivation (Jhum) and natural forest of Khasi pine and terraced agriculture (Maize). Agroforestry practices significantly improved the soil physical, chemical and biological properties such as soil aggregation, water holding capacity, erosion susceptibility, soil organic carbon, microbial biomass carbon, basal respiration etc. The improvement was more pronounced in alder based agro forestry practices. Soil quality index (SQI) was also highest for Alder + large cardamom (0.858) followed by Alder + Tea +Black pepper (0.758) and Alder + Ginger (0.756). The study inferred that alder based agro forestry practices not only prevented from land degradation but improved the soil health and environmental sustainability. When shifting cultivation is unavoidable, the land restoration should be done with the help of alder based agro forestry practices to sustain its production and ecological functions.
\end{abstract}

Keywords: Agroforestry, hilly ecosystem, pine forest, soil health, shifting cultivation

\section{Introduction}

Soil degradation induced by land use change is a major problem across many ecosystems of the world including north-eastern Himalayan Region (NEHR) of India. Worldwide, conversion of natural forests to agriculture (both shifting and settled agriculture) is contributing to deforestation of 13 million ha area every year (FAO, 2006) ${ }^{[9]}$. Between 1950 to 2010, in India alone, about 8.30 million ha forest land was converted to produce agricultural crops (Tian et al., 2014) ${ }^{[31]}$. In the NEHR of India, shifting cultivation or jhuming along the steep slopes, an age old practice of the local tribe's one of the major reasons for causing severe land degradation. It is not only a tradition of the tribal population of the region but a way of life and deeply ingrained in their cultural heritage (Singh et al., 2014) ${ }^{[28]}$. In the jhum cultivation, the existing forest vegetation is slashed and piled between mid-Decembers to mid-February and burnt. The ash is spread over the whole field and crops like Ginger, Colocasia, tapioca, pumpkin, maize, chilli etc. are planted/sown during April-May of the first year. In the second year upland rice (un-puddle rice) is cultivated in broadcasting method. Rarely the jhum field is cultivated in the $3^{\text {rd }}$ year after which it is abandoned. On the abandoned jhum fields, broom grasses (Thysanolaena maxima) are cultivated which is one of the economic grass species of the region. Inflorescence of this grass species is used for preparation of broom and the foliage is used as a fodder in the winter when no other green fodder is available in the region. In the Meghalaya state alone, about 26,000 tonnes of dry broom grass inflorescence is produced per annum (Tiwari et al., 2012) ${ }^{[32]}$. Jhumis practiced in 0.76 million ha land area in the NEHR (Wasteland Atlas of India, 2010) ${ }^{[38]}$ and burns more than 8.5 million tonnes phytomass (including forest floors) annually (Choudhury et al., 2016) ${ }^{[4]}$. Khasi pine (Pinus kesiya) is a pioneer tree species in the region, which comes up on newly exposed soil surfaces deficient in profile moisture and nutrients. 
Other broad leaved vegetation's come up after the Pinus kesiya vegetation attains the climatic climax. In the hills, these Pinus kesiya forests are slashed, burnt and converted to jhum land, exposing the steep slopes to severe soil erosion and land degradation. Nearly $30 \%$ of the region is classified under severe erosion category having potential erosion rate of 40-80 t/ha/year (Mandal and Sharda, 2013) ${ }^{[20]}$. Only $15.7 \%$ area is under agricultural use because of undulating hilly topography (Choudhury et al., 2016) ${ }^{[4]}$. To avoid land degradation in such fragile hilly ecosystem while meeting the food, fodder and fuel needs of the burgeoning population living in a distinct socio-cultural environment, some complementary or alternative land use practices are needed to maintain the production and service functions of the hill ecosystem in perpetuity.

Agroforestry system, which compulsorily retains a woody perennial either in spatial or temporal sequence, is a promising complementary system to achieve sustainable productivity in great harmony with soil environment. Many tree species have been traditionally used in the region because of their multiple benefits. Cultivation of large cardamom under Alnus nepalensis is an ancient practice in Sikkim state which produces more than 86 percent of the total large cardamom produced in India (source: www.kiran.nic.in/ sikkim_pride.html). Over the past 30 years, many agro forestry systems had been developed in the $\mathrm{NEH}$ region (Dhyani and Tripathi, 2000) ${ }^{[8]}$ as alternative to jhuming, but, the effect of such Land use practice on soil health and its quantification based on multiple soil quality attributes having datasets covering the whole range of soil physical, chemical and biological attributes has not yet been studied. Only few case studies had been carried out with less comprehensive dataset (Dhyani et al., 1994) ${ }^{[7]}$.

It is difficult to judge soil aggradation or degradation of a particular Land use by only studying few soil parameters. So, to assess the overall soil health response to Land use changes and their relative comparison, Soil Quality Index (SQI) is commonly used in many ecosystems of the world. Soil quality is a broad function of soil properties which provides guidelines for devising management practices that can improve different soil functions. Since the introduction of soil quality concept by Warkentin and Fletcher (1977) ${ }^{\text {[37] in }}$ assessing soil health response to management, many dimensions have been added in terms of quantitative and multi-parametric approaches in SQI (Larson and Pierce, 1991; Karlen et al., 2003) ${ }^{[17,15]}$. But, information about the response of agro forestry systems to soil health and quality parameters is very scanty for hilly ecosystems including the NEHR of India. Therefore, we studied comprehensively the effects of 25 years old six multipurpose tree (MPT) based agro forestry practices (AFP) established by clearing pine forests on soil quality attributes (physical, chemical and biological) at midaltitude $(>1000 \mathrm{~m}$ asl $)$ of Meghalaya, NEHR. The tree components consisted of Alnus nepalensis (nitrogen fixing MPT), Michelia champaka (most popular timber tree in the region), Michilus bombycina (tree used for rearing silk worm) and Grivelia robusta (a fast growing MPT commonly used for fuel and shade tree). In the region, for meeting food requirements, slash and burn (Jhum) agriculture in steep slopping lands is prevalent while maize cultivation in the uplands (including terracing) is the most commonly used agricultural practices. Therefore, we compared AFS with a two years old jhum land which was established after clearing pine forests (traditional land use) and maize based terraced agriculture in the vicinity of the agro forestry practices. Similarly, primary pine forests are the dominant vegetation's (forests) in the slopping uplands of the region. To complement the comparison, soil attributes of a native Pinus kesiya (pine) forests near to the experimental field was evaluated. We also quantified the relative differences in the ability of different agro forestry Practices (AFP) in terms of soil health aggradations or degradation in reference to native pine forests and degraded jhum lands with the help of SQI estimates.

\section{Materials and Methods \\ Experimental site and climate}

The study was carried out at ICAR Research Complex for $\mathrm{NEH}$, Meghalaya, and Northeast India (between $25^{\circ} 39^{\prime}$ to $25^{\circ}$ $41^{\prime} \mathrm{N}$ latitude, $91^{\circ} 54^{\prime}$ to $91^{\circ} 63^{\prime} \mathrm{E}$ longitude and $952-1082 \mathrm{~m}$ ASL altitude). The area experiences tropical monsoon climate, $70 \%$ of the total annual rainfall $(2450 \mathrm{~mm})$ is received during July to September (Fig 1). April is the hottest month, with average minimum and maximum temperatures of $17.3^{\circ} \mathrm{C}$ and $29.4{ }^{\circ} \mathrm{C}$, respectively. The coldest month is December where the average minimum and maximum temperatures are $7.6{ }^{\circ} \mathrm{C}$ and $20.4{ }^{\circ} \mathrm{C}$, respectively. Average sunshine hour's are 5.42hr/day (Choudhury et al., 2012) ${ }^{[3]}$.

\section{Land uses evaluated}

Six different agro forestry practices (AFPs: >25 years old) were established in 1983 at agro forestry farm of ICAR Research Complex for NEH Region and since then, treeagriculture-horticulture-grass species combinations have been maintained. The tree species in the AFPs were planted on alternate terraces with a spacing of $5 \times 5 \mathrm{~m}\left(400\right.$ trees ha $\left.^{-1}\right)$. The average width of terraces was 1.2 to $1.5 \mathrm{~m}$. The six AFPs are:

1) Alder + Tea + Black pepper (Alnus nepalensis + Camellia sinensis + Piper nigrum),

2) Silver oak +Pineapple (Grevillea robusta + Ananascomosus),

3) Som +Broom +Pineapple (Machilus bombycina + Thysanolaena maxima +Ananas comosus),

4) Alder +Large cardamom (Alnus nepalensis + Amomum subulatum),

5) Alder +Ginger (Alnus nepalensis +Zingiber officinale), and 6) Gumhar +Turmeric (Gmelina arborea + Curcuma longa).

In Alder + Tea + Black pepper, Tea seedlings were planted in two rows on each terrace and the average plant to plant distance was $60 \mathrm{~cm}$. Black pepper vines variety (Panniyur 1 and 2) were trailed on each alder plant. In the second AFPs, pineapple var. Kew was planted in paired rows at $50 \mathrm{~cm} \mathrm{x}$ $50 \mathrm{~cm}$ spacing. The planting arrangement in Som +Broom + Pineapple was more complicated. Broom grass was planted at plant to plant distance of $90 \mathrm{~cm}$ and one to two rows were planted on each terrace depending on the terrace width. Pineapple var. Kew was planted in paired rows at $50 \mathrm{~cm} \mathrm{x}$ $50 \mathrm{~cm}$ spacing. Broom and pineapple were planted on alternate terraces. In the Alder +Large cardamom AFP, large cardamom was planted at a spacing of $90 \mathrm{~cm}$ on each terrace. Ginger var. Nadia was planted at a spacing of $40 \mathrm{~cm} \times 40 \mathrm{~cm}$ and turmeric var. Megha Turmeric 1 was planted at a spacing of $50 \mathrm{~cm} \mathrm{x} 50 \mathrm{~cm}$ with Alder +Ginger and Gumhar +Turmeric 
AFP, respectively. Both ginger and turmeric were planted on paired rows on the terraces. Since the soils in the selected area is extremely acidic $(\mathrm{pH}<4.5)$, a basal dose of $1.5 \mathrm{t} \mathrm{ha}^{-1}$ lime was applied before two weeks of sowing in agricultural crops in 1983. Around $10 \mathrm{~kg}$ well rotten farmyard manure (FYM) per pit was applied at the time of planting across all tree species. Recommended fertilizer doses of Nitrogen, Phosphorus and Potash for the region in the form of urea, diammonium-phosphate (DAP) and murate of potash (MOP) were applied in black pepper, pineapple, tea, ginger, turmeric and maize in the bench terraces in all the plots and maintained since 1983. Standard cultural practices were followed for management of these agricultural/ spices/plantation crops since 1983. The tree species were pruned during DecemberJanuary of every year to allow enough light on the under storey vegetation. Every third year heavy pruning is imposed on the tree species. In order to compare the impact of AFPs on soil health and quality, three predominant traditional Land uses namely Shifting cultivation (Jhum system), Terrace Agriculture (Maize: Zea mays) and Primary pine forest (Pinus kesiya) situated in the vicinity were also included in the evaluation.

\section{Soil sampling and analysis}

From each of the six AFS, we selected five locations at random, and from each location surface soils $(0-15 \mathrm{~cm})$ were collected in March 2011 before the onset of monsoon. Similarly, from each of three traditional Land uses (Jhum, maize and pine forests), surface soils $(0-15 \mathrm{~cm})$ from five locations were collected randomly. Undisturbed samples were used for determination of soil hydro-physical properties- soil aggregation (MWD: mean weight diameter) by wet sieving method (Yoder, 1936) ${ }^{[40]}$, water holding capacity (WHC) by Raczkowski box method (Gupta and Dakshinamoorthi, 1980) ${ }^{[12]}$, plant available water content (PAWC) by pressure plate apparatus(difference in water content between 0.33 bar and 15 bar pressures) and soil bulk density (BD) by core method (Blake and Hartge, 1986) ${ }^{[2]}$ using cores of $6.0 \mathrm{~cm}$ in height and $6.0 \mathrm{~cm}$ in diameter.. Dispersion (DR) and erosion ratios (ER) were calculated by sedimentation method (Middleton, 1930) ${ }^{[21]}$. In-situ infiltration rate was measured by double ring Infiltrometer in five random locations in each of the nine Land uses. For the interpretation of susceptibility to soil erosion, threshold/ critical limits of DR and ER were taken as

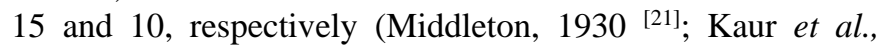
2003) ${ }^{[16]}$.

For analysis of biological properties of the soil, fresh undisturbed sub-samples after removing stones, roots, crop residues etc. were placed in sealed plastic bags, and stored at $2{ }^{\circ} \mathrm{C}$ in the refrigerator. From these sub-samples, we determined dehydrogenate activity (DHA) by TPF reduction method (Casida, 1977), basal respiration (BR) by alkali trap method (Mac Fayden 1970) ${ }^{[19]}$, phosphates activity (PA) by p-nitrophenol extraction method (Tabatabai and Brenner, 1969) ${ }^{[30]}$, and soil microbial biomass carbon (SMBC) by chloroform fumigation extraction method (Vance et al., 1987) [33].

Air dried samples sieved through the 2-mm sieve were used for soil textural analysis using a Buyoucous scale, while $0.5 \mathrm{~mm}$ sieved samples were analyzed for SOC estimation by wet digestion method (Walkley and Black, 1930) ${ }^{[35]}$. Air dried 2-mm sieved samples were analyzed for $\mathrm{pH}$ (1:2 soil: water), exchange acidity, cations $\mathrm{Ca}^{2+}, \mathrm{Mg}^{2+}$ extracted in ammonium acetate at $\mathrm{pH}$ 7.0, available nitrogen (N) by alkaline potassium permanganate (Subbiah and Asija, 1956) [29], available phosphorus (P) by Brays-II, available potassium (K) by $1 \mathrm{M} \mathrm{NH}$ OAC and measured by flame photometer, available sulfur $(\mathrm{S})$ by the turbidimetric procedure (Jackson, 1973) ${ }^{[13]}$. Exchangeable aluminum $\left(\mathrm{Al}^{3+}\right)$ content was determined colorimetrically after extraction with $1 \mathrm{M} \mathrm{KCl}$ (Lin and Coleman, 1960) ${ }^{[18]}$.

\section{Statistical analyses and development of soil quality index}

Twenty seven (27) soil attributes were measured from the different AFPs and three traditional Land uses. All of them were checked for the normality of distribution. The design of sampling across all the Land use practices led to a simple balanced one-way analysis of variance (ANOVA) with nine Land uses as treatments and residual within-treatment completely randomized structure. SAS version 9.2 (SAS Institute, 2010) [25] was used to analyse the data. The treatments were compared based on Duncan's Multiple Range Test (DMRT) at 5\% probability level. Pearson's correlation coefficient was estimated between all the 27 pairs of attributes and their significance tested at $5 \%$ level of significance.

Soil quality index (SQI) was developed following four major steps:

i) Indicator selection and generation of minimum data set (MDS),

ii) Setting up of scoring values for the indicators and transforming them into 0 to 1 scale,

iii) Assigning weight to different indicators,

iv) Assembling the indicators into SQI and testing the significance of their differences across Land uses.

Minimum data set (MDS) was formed by eliminating the redundant variables through Principal component analysis (Andrew et al., 2002) which helped to reduce large number of correlated variables to a smaller number of uncorrelated components (factors) that explained most of the variations in the dataset. The direction of the maximum variability was estimated by Eigen vectors and the scale of variability was explained by the Eigen value of a particular principal component. Standardized PCA with Varimax rotation of data was performed to maximize correlation between the PCs and the measured attributes. Only the PCs having eigen values $>1$ were retained as PCs with eigen values $<1$ explain less variance than the individual variables. Under a particular PC, each variable had a factor loading that represents the contribution of that variable to the composition of the PC. Only the highly weighted variables (factor loading $\geq 0.50$ ) were retained from each PC for constituting the MDS (Wander and Bollero, 1999) ${ }^{[36]}$. When more than one variable was retained under a single PC, Pearson's correlation coefficient was used to determine if the variables could be considered redundant and, accordingly eliminated from the MDS. Non-correlated variables with high factor loading were retained in the MDS.

Before developing and testing composite SQI, we scored each indicator and set the boundaries and shape of the scoring function. This resulted in normalization of units/scales of all indicators for making a composite index. The soil parameters were transformed into 0 to 1 scale using 3 types of standardized scoring functions

i) More is better.

ii) Less is better.

iii) Optimum is better.

Indicators were ranked in ascending or descending order depending on whether a higher value was considered 'good' 
or 'bad' in terms of soil function. For 'more is better' indicators, each observation was divided by the highest observed value such that the highest observed value received a score of 1. For 'less is better' indicators, the lowest observed value (in the numerator) was divided by each observation (in the denominator) such that the lowest observed value received a score of 1 (Andrews et al., 2002) ${ }^{[1]}$. Each individual variable of the MDS was assigned a weight, which was calculated as the ratio of the indicator communality value to the cumulative communality of the selected factors. Finally soil quality index was estimated for different Land use systems as Andrews et al. (2002) ${ }^{[1]}$,

Soil Quality Index $(S Q I)=\sum_{i=1}^{n} W i V i$

Where,

$W i=$ Weight of variables and $V i=$ Score of variables

Here the assumption is that higher index score mean better soil quality or greater performance of soil function. Analysis of variance was performed on the replicated SQI values and the different systems were compared by Duncan's Multiple Range Test (DMRT).Since, all the Land uses (either jhum or agro forestry) were created by clearing the natural pine forest, we considered Pine forest as a reference SQI and assessed the impact of other modified Land uses on soil health as degrading or aggrading.

\section{Results and Discussion \\ Effect of Land uses on physical, chemical and biological properties}

Adoption of different agroforestry practices (AFPs) by clearing pine forests significantly $(p<0.05)$ improved the soil hydro-physical properties as compared to jhum cultivation (Table 1). Water holding capacity was improved by 28 to $33 \%$ while PAW was by $6-7 \%$ in Silver Oak +Pineapple and Alder +Large cardamom based AFP over traditional Land uses including maize based terraced agriculture and pine forests. Conversion from pine forests to jhum land resulted in lowest WHC as well as PAW. Similarly, AFPs significantly $(p<0.05)$ improved soil aggregation over traditional Land uses: the mean weight diameter (MWD) of AFPs was 20\% higher than traditional jhum and maize based terrace agriculture (3.33-3.51mm). Some of the AFPs improved soil aggregation (indicator-MWD) by $9-15 \%$ over natural pine forests (Table 1). AFPs also moderated the too high infiltration rate (IR) and saturated hydraulic conductivity (HC) measured in natural pine forests and thus, increased water retention (WHC \& PAW). However, adoption of jhuming in natural pine forests reduced IR and $\mathrm{HC}$ significantly (by over 60\%), that made the soil susceptible to surface runoff and erosion. This was evident from the $81 \%$ increase in erosion ratios (ER: $25.9 \%$ ) in jhum lands over pine forests, which was many folds higher than the critical threshold limit (ER: 10\%) for erodibility. Most of the hydrophysical properties in jhum land, particularly, degeneration of soil structure, as evident from significant reduction in water stable aggregates and mean weight diameter, is a major concern. Due to burning of phytomass, exposure of surface soils and repeated anthropogenic soil disturbances including tillage practices along the steep slopes encouraged loss of cementing agents including organic carbon, phosphorous, finer clay fractions and bases $(\mathrm{Ca}+\mathrm{Mg})$ through the action of high intensity rainfall and associated runoff and soil erosion. Jhum lands lost top fertile soils including bases; soils became more acidic and low in plant available nutrients $(\mathrm{N}, \mathrm{P}, \mathrm{K}$ and $\mathrm{S})$. The particle size distribution reflected abrupt textural changes in jhum soils: dominated by sand fraction (>72\% compared to $49.9 \%$ in pine forests). This has resulted in degeneration of soil structure having higher levels of compaction, significant reduction in water transmission (low infiltration and conductivity rate) and retention (reduced WHC). Jhum land also remained most susceptible to erosion that exceeded threshold levels of dispersion and erosion ratios. The terrain has steep slope and experiences high monsoonal rains (more than $2500 \mathrm{~mm}$ per annum), the annual soil loss from the exposed soils under jhum cultivation in the region has been reported in the range of 49-200t/ha (Prasad, 1987) ${ }^{[23]}$.Repeated tillage practices and disturbances of surface soils in nutrient exhaustive maize based agriculture also encouraged partial loss of organic carbon, bases ( $\mathrm{Ca}$ $+\mathrm{Mg}$ ) and other cementing agents for aggregate formation. As a result, despite external supplementation of plant nutrients through fertilization, poor soil aggregation (low MWD), water transmission and retention, and higher susceptibility to erosion was observed in maize based system. Zhao et al. (2005) ${ }^{[41]}$ reported that conversion of natural vegetation into crop land destroyed the surface cover leading to accelerated soil erosion and resulted in coarseness in soil texture, decline in soil C and nutrients. Decrease in P in jhum land, pine forest and terraced agriculture might be due to reduction in organic matter content, decrease in soil $\mathrm{pH}$ which could have enhanced $\mathrm{P}$ fixation and reduced biological activities (Schroth et al., 2001 [26]; Garcia Gil et al., 2000) [10]. High water transmission in pine forests indicated that the soils might have some preferential flow pathways (fissures), developed over the years of root decay and associated factors free from anthropogenic soil disturbances. On the other hand, adoption of the AFPs especially, Alder +large cardamom and Som +Broom +Pineapple, substantially reduced the susceptibility of soil to erosion than in the pine forests. Dispersion (DR) and erosion ratios (ER) in AFPs were below the threshold limits (DR: 15 and ER: 10) while it was above critical threshold limit in traditional Land uses including pine forests.Adoption of AFP on clear felled pine forests over the years significantly improved most of the soil hydro-physical and fertility attributes over the traditional Land uses (Jhum and terraced agriculture) including undisturbed pine forests. Soil aggregation was stronger with higher water retention in AFPs. Due to increase in cementing agents for aggregation (bases, organic carbons, clay fractions as well as nutrient-P), susceptibility of soil to erosion was significantly reduced (low DR \& ER) below critical threshold level compared to traditional Land uses (Saha and Mishra, 2007) ${ }^{[24]}$. Soil became less acidic in reaction and had better availability of plant nutrients $(\mathrm{N}, \mathrm{P}, \mathrm{K}$ and $\mathrm{S}$ ) compared to the traditional Land uses. This improvement could be attributed to higher above and below ground biomass in the tree based AFPs, whichmight have augmented the nutrient turn over, thus decreasing the soil acidity while increasing the nutrient availability. Similar rise in soil $\mathrm{pH}$ under 15 years old MPTs was also reported in the region by Datta and Singh (2007) ${ }^{[5]}$. Higher tolerance limit of agro forestry system to erosion could be ascribed to the effect of heavy litter fall, which might have increased the cohesiveness in the soil system after decomposition and aggregated soil particles tightly in lower horizons by their deep root systems (Deb et al., 2005) ${ }^{[6]}$. This 
was also evident from the soil aggregation (MWD sizes) and higher SOC content in the AFPs. Grewal and Abrol (1986) ${ }^{[11]}$ reported that the litter falls on the ground and surface vegetation protected soil directly against erosive forces of raindrops and surface run-off by improving soil hydrological parameters.

The soils across the Land uses were acidic in nature $(\mathrm{pH}$ <4.90) (Table 1). In the Som +broom +pineapple based AFP, soil $\mathrm{pH}$ increased by 0.47 units over jhum cultivation $(\mathrm{pH}=$ 4.36). All AFPs except Alder +Ginger and Gumhar +Turmeric had higher concentration of bases $\left(\mathrm{Ca}^{2+}\right.$ and $\left.\mathrm{Mg}^{2+}\right)$ over the traditional jhum land and terraced agriculture (Maize). The pine forest had significantly $(p<0.05)$ higher exchangeable $\mathrm{Al}^{3+}$ contents despite comparable soil $\mathrm{pH}$ with some of the AFP (Table 1). Soils were by and large, high $(>1.6 \%)$ in organic carbon content (Table 1). The three AFPs namely, Alder + Tea + Black pepper, Alder + Large Cardamom and Som +Broom +Pineapple recorded $24 \%$ to $43 \%$ more organic carbon than traditional jhum land and natural pine forests. Alder based agro forestry system (Alder + Ginger and Alder +Large cardamom) had significantly $(p<0.05)$ higher available $\mathrm{N}, \mathrm{P}$ and $\mathrm{K}$ contents compared to traditional Land uses. Higher fertility status of Alder +Tea +Black Pepper and Alder + Large cardamom based systems could be due to nitrogen fixing ability of alder species, solubilisation of native $\mathrm{P}$ owing to root exudates and addition of organic matter through fine roots (Dhyani et al., 1994) ${ }^{[7]}$, minimum tillage of the soil as all the component crops of the system are perennial. Average annual $\mathrm{N}$ fixation in Alnus nepalensis was reported to the tune of $117-235 \mathrm{~kg} / \mathrm{ha}$ in the Himalayan region (Sharma, 1993) ${ }^{[27]}$. Dhyaniand Tripathi (2000) ${ }^{[8]}$ reported that Alnus nepalensis produced 3.93 t/ha fine root biomass per annum in the NEHR of India. Higher root biomass (mostly active fine roots), litter deposition coupled with Frankia based nitrogen fixation, retrieval of deeper layer phosphorus (Nair et al., 1995) [22] and mycorrhizal transformation, enhancement in soil aggregation made Alnus nepalensis a better agro forestry tree for maintaining soil health than the other dominant trees available in this hilly ecosystem. Lower erosion and dispersion ratio values in these systems further made them a potential alternative for soil and water conservation.

Among all the Land uses, jhum land recorded extremely low Brays-II available P (9.2 kg/ha) followed by pine forests (13.1 $\mathrm{kg} / \mathrm{ha}$ ). Effect of Alder based AFP (Alder + Tea +Black pepper and Alder +Large cardamom) also significantly $(p<0.05)$ improved soil biological properties: increased the SMBC, DHA, BR and phosphatase activity as compared to the other AFPs and pine forest. In the agro forestry systems, significant improvement in these attributes over jhum land as well as pine forests might be due to better structural regeneration, balance in aeration-moisture-thermal regimes, higher organic carbon and nutrients availability, which provided a congenial environment for microbial growth and augmented other soil restoration processes (Deb et al., 2005) ${ }^{[6]}$. Correlation analysis between microbial attributes and other soil quality attributes also reaffirmed it. Conversion of natural pine forests to jhum land, in a short span of 2 years, resulted in significant $(p<0.05)$ deterioration of soil microbial properties (SMBC, DHA, BR and PA) because of slashing and burning. Reduced soil microbial properties (SMBC, BR, DHA and PA) in jhum soils could be due to deterioration of soil hydro-physical (aggregation, water retention and transmission) and fertility attributes (low $\mathrm{pH}$, organic carbon

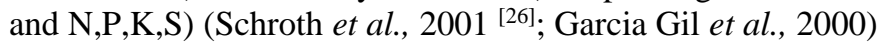

[10]. Vanlalhruaia et al. (2005) [34] also reported lower microbial biomass carbon (MBC) and dehydrogenase activities under one year old shifting cultivated land as compared to undisturbed forest and horticultural plantation. In comparison to jhum land, adoption of AFP in pine forests rather significantly improved soil microbial attributes (Table 1).

Correlation analysis revealed that soil aggregation (MWD) was significantly and positively influenced $(r=+0.43-0.54)$ by finer fractions (clay + silt), SOC contents and bases $(\mathrm{Ca}+\mathrm{Mg})$ (Table 2). Soils with higher MWD had lesser erosion susceptibility and better water holding capacity which is evident from the negative correlation of MWD with ER and DR ( $r=-0.40$ to- 0.55$)$ and positive correlation with WHC and FC. Available macronutrients-NPK and SOC content significantly and positively influenced $(r=0.55-0.74)$ soil microbial properties (SMBC, BR, DHA \& PA). Similarly, better aggregation (MWD) also positively influenced soil microbial properties (SMBC, BR, DHA \& PA).

\section{Development of Soil Quality Index (SQI)}

Significant correlation $(p<0.05)$ among many pairs of variables (Table 2) indicated the tendency of the Land use practices to influence a group of variables in specific ways which were highly inter-correlated. With the use of PCA, we reduced 27 parameters to six principal components that cumulatively explained $80.66 \%$ of the variation (Table 3 ). First PC explained $43.3 \%$ variance and was closely related to particle size distribution (sand, silt, and clay) while second PC explained $12.9 \%$ variance and was related to fertility functions (available $\mathrm{P}, \mathrm{K}, \mathrm{DHA}, \mathrm{BR}$, and phosphatase activity).The remaining 4 PC's (PC3 to PC6) explained 24\% variance and were closely related to soil erosion function (dispersion ratio, infiltration rate and bulk density)(PC3), soil hydraulic function (bulk density and mean weight diameter, SOC content) (PC4), soil acidity function $(\mathrm{pH}$ and $\mathrm{Ca}+\mathrm{Mg}$ ) (PC5) and soil water retention function (Field capacity and plant available water) (PC6), respectively. Based on the factor loadings, the minimum data set (MDS) was constituted of variables such as organic carbon, basal respiration, available sulphur, sand content, soil $\mathrm{pH}$, and plant available water content. Based on the communality values, highest weight was ascribed to sand content followed by SOC, available sulphur, plant available water, basal respiration and soil $\mathrm{pH}$ (Table 4).Analysis of variance revealed that all the six AFPs improved SQI values at varying magnitudes over pine forests: $3 \%$ in Alder + ginger to $21 \%$ in Alder + Large cardamom (Table 4). In contrast, jhuming resulted in $10 \%$ decrease in SQI values over the pine forest (SQI: 0.705).Among all the AFPs and three Land uses, Alder + Large cardamom based AFP had the highest SQI value (0.858) while traditional jhum land registered the lowest (0.637) SQI value. The SQI for maize based terrace agriculture (Table 4) was in between Alder +Large cardamom and pine forest (0.705) system. Improvement of overall soil quality attributes on adoption of AFP, particularly by $\mathrm{N}$-fixing alder based systems such as Alder +Large cardamom, and Alder + Tea +Black pepper resulted in significant increase in SQI values compared to traditional Land uses (Jhum, agriculture and pine forests). Although Som +Broom +Pineapple did not have any nitrogen fixing components in the system and the litter fall was much lesser than alder (data not presented), the SQI values were significantly higher than jhum and natural pine forests. This could be due to higher root biomass including root length density (Winkler, 2015) ${ }^{[39]}$ contributed by broom grass to the 
system that improved soil binding ability, and reduced soil loss. Higher conservation efficiency and soil binding capacity of broom grass was also reported by Kafle and Balla (2008) ${ }^{[14]}$ in Nepal.

From the SQI values, it could be inferred that the practice of jhuming encouraged the severity of soil quality degradation of even an established natural pine forests at a much faster rate (within a short span of 2 years) while adoption of alder based AFPs on a clear felled pine forest improved the soil quality substantially over a period of 25 years that would sustain food-fodder-fuel production chain on the undulating steep slopes of the hilly ecosystem. In other AFPs also, soil health was either aggraded or remained unchanged compared to natural pine forests. Alder (Alnus nepalensis) based agroforestry practices, which were imposed as human mediated Land use could improve the soil health much faster than the Pinus kesiya forest which also improved the soil in a natural process Therefore, Alnus nepalensis can be used as a preferred tree species in the agroforestry systems for faster restoration of soil health in the slopping lands of NE India.

Tables and Figures

Table 1: Response of physical, chemical and biological soil attributes to the different Land use systems

\begin{tabular}{|c|c|c|c|c|c|c|c|c|c|}
\hline Parameter & \begin{tabular}{|l|} 
Alder + Tea + \\
Black Pepper
\end{tabular} & $\begin{array}{c}\text { Silver oak + } \\
\text { Pineapple }\end{array}$ & $\begin{array}{c}\text { Som + Broom } \\
\text { +Pineapple }\end{array}$ & $\begin{array}{c}\text { Alder + Large } \\
\text { cardamom }\end{array}$ & $\begin{array}{c}\text { Alder + } \\
\text { Ginger }\end{array}$ & $\begin{array}{l}\text { Gumhar + } \\
\text { Turmeric }\end{array}$ & Jhum & $\begin{array}{l}\text { Agriculture } \\
\text { (Maize) }\end{array}$ & $\begin{array}{l}\text { Pine } \\
\text { forest }\end{array}$ \\
\hline $\mathrm{pH}$ & $4.43^{\mathrm{d}}$ & $4.52^{\mathrm{c}}$ & $4.83^{\mathrm{a}}$ & $4.59^{\mathrm{b}}$ & $4.53^{\mathrm{c}}$ & $4.47^{\mathrm{d}}$ & $4.36^{\mathrm{e}}$ & $4.52^{\mathrm{c}}$ & $4.53^{\mathrm{c}}$ \\
\hline $\begin{array}{c}\mathrm{Ex}^{\mathrm{A}} \mathrm{Al}^{3+} \\
\text { (meq/100 g soil) }\end{array}$ & $1.23^{\mathrm{b}}$ & $1.25^{\mathrm{b}}$ & $0.80^{f}$ & $1.08^{\mathrm{d}}$ & $1.13^{\mathrm{cd}}$ & $0.91 \mathrm{e}$ & $0.92 \mathrm{e}$ & $1.15 \mathrm{c}$ & $1.43^{\mathrm{a}}$ \\
\hline SOC $(\%)$ & $2.41^{\mathrm{a}}$ & $1.92^{\mathrm{bc}}$ & $2.14^{\mathrm{ab}}$ & $2.11^{\mathrm{ab}}$ & $1.72^{\mathrm{c}}$ & $1.70^{\mathrm{c}}$ & $1.69^{c}$ & $1.96^{\mathrm{bc}}$ & $1.73^{\mathrm{c}}$ \\
\hline Av. N (kg/ha) & $265.9^{\mathrm{bc}}$ & $260.9^{\mathrm{bc}}$ & $268.4^{\mathrm{b}}$ & $275.9^{\mathrm{b}}$ & $297.9^{\mathrm{a}}$ & $250.8^{\mathrm{c}}$ & $200.1^{\mathrm{d}}$ & $251.6^{\mathrm{c}}$ & $208.2^{\mathrm{d}}$ \\
\hline Av. P (kg/ha) & $26.4^{\mathrm{bc}}$ & $19.9^{\mathrm{dc}}$ & $20.5^{\mathrm{dc}}$ & $33.3^{\mathrm{ab}}$ & $35.4^{\mathrm{a}}$ & $18.1^{\mathrm{d}}$ & $9.2^{\mathrm{e}}$ & $17.4^{\mathrm{d}}$ & $13.1^{\mathrm{de}}$ \\
\hline Av. K (kg/ha) & $346.4^{\mathrm{a}}$ & $311.1^{\mathrm{bc}}$ & $349.4^{\mathrm{a}}$ & $356.9^{\mathrm{a}}$ & $331.3^{\mathrm{ab}}$ & $279.0^{\mathrm{d}}$ & $254.0^{\mathrm{e}}$ & $306.6^{\mathrm{bcd}}$ & $287.6^{\mathrm{cd}}$ \\
\hline $\begin{array}{c}\mathrm{Ca}^{2+}+\mathrm{Mg}^{2+}(\mathrm{meq} / 100 \\
\text { g soil })\end{array}$ & $6.48^{\mathrm{b}}$ & $5.57^{\mathrm{bc}}$ & $8.07^{\mathrm{a}}$ & $7.91^{\mathrm{a}}$ & $5.14^{\mathrm{cd}}$ & $3.44 \mathrm{f}$ & $4.50 \mathrm{~d}$ & $3.67 \mathrm{ef}$ & $7.86^{\mathrm{a}}$ \\
\hline Av. S (kg/ha) & $10.8^{\mathrm{c}}$ & $12.2^{\mathrm{c}}$ & $12.6^{\mathrm{c}}$ & $17.5^{\mathrm{b}}$ & $15.6^{\mathrm{b}}$ & $21.0^{\mathrm{a}}$ & $12.6^{\mathrm{c}}$ & $17.4^{\mathrm{b}}$ & $10.4^{\mathrm{c}}$ \\
\hline $\mathrm{HC}(\mathrm{cm} / \mathrm{hr})$ & $10.59^{\mathrm{ab}}$ & $5.57^{\mathrm{c}}$ & $8.96^{\mathrm{abc}}$ & $6.28^{\mathrm{bc}}$ & $6.96^{\mathrm{bc}}$ & $6.38^{\mathrm{bc}}$ & $7.32^{\mathrm{bc}}$ & $5.08^{\mathrm{c}}$ & $12.90^{\mathrm{a}}$ \\
\hline MWD (mm) & $4.18^{a b c}$ & $4.21^{\mathrm{ab}}$ & $4.24^{\mathrm{a}}$ & $4.04^{\mathrm{bc}}$ & $3.92^{\mathrm{de}}$ & $3.79^{\mathrm{cd}}$ & $3.33^{\mathrm{e}}$ & $3.51^{\mathrm{de}}$ & $3.68^{\mathrm{cd}}$ \\
\hline IR $(\mathrm{mm} / \mathrm{hr})$ & $11.99^{\mathrm{b}}$ & $7.92^{\mathrm{d}}$ & $10.01^{\mathrm{c}}$ & $6.01^{\mathrm{e}}$ & $7.99^{\mathrm{d}}$ & $6.01^{\mathrm{e}}$ & $5.60^{\mathrm{e}}$ & $8.56^{\mathrm{d}}$ & $14.00^{\mathrm{a}}$ \\
\hline PAW (\%) & $18.98^{\mathrm{cd}}$ & $24.09^{\mathrm{a}}$ & $17.39^{\text {cd }}$ & $23.16^{\mathrm{ab}}$ & $21.24^{\mathrm{b}}$ & $18.58^{\mathrm{cd}}$ & $17.39^{\mathrm{d}}$ & $19.27^{\mathrm{c}}$ & $18.1^{\mathrm{cd}}$ \\
\hline DR (\%) & $15.4^{\mathrm{bc}}$ & $13.4^{\mathrm{cd}}$ & $13.0^{\mathrm{de}}$ & $11.0^{\mathrm{e}}$ & $14.0^{\mathrm{bcd}}$ & $13.0^{\mathrm{de}}$ & $19.2^{\mathrm{a}}$ & $15.9^{\mathrm{b}}$ & $19.2^{\mathrm{a}}$ \\
\hline Max. WHC (\%) & $52.9^{\mathrm{bc}}$ & $54.92^{\mathrm{abc}}$ & $56.17^{\mathrm{ab}}$ & $57.23^{\mathrm{a}}$ & $57.21^{\mathrm{a}}$ & $54.15^{\mathrm{abc}}$ & $42.97^{\mathrm{e}}$ & $50.96^{\mathrm{cd}}$ & $48.32^{\mathrm{d}}$ \\
\hline ER $(\%)$ & $11.5^{\mathrm{c}}$ & $9.5^{\mathrm{d}}$ & $8.9^{\mathrm{d}}$ & $9.3^{\mathrm{d}}$ & $10.2^{\mathrm{cd}}$ & $10.0^{\mathrm{cd}}$ & $25.9^{\mathrm{a}}$ & $14.7^{\mathrm{b}}$ & $14.3^{\mathrm{b}}$ \\
\hline $\mathrm{BD}\left(\mathrm{Mg} / \mathrm{m}^{3}\right)$ & $1.18^{\mathrm{c}}$ & $1.25^{\mathrm{ab}}$ & $1.19^{\mathrm{bc}}$ & $1.19^{\mathrm{c}}$ & $1.27^{\mathrm{a}}$ & $1.17^{\mathrm{c}}$ & $1.28^{\mathrm{a}}$ & $1.14^{\mathrm{c}}$ & $1.29^{\mathrm{a}}$ \\
\hline FC Vol.\% & $39.6^{\mathrm{bc}}$ & $42.9^{\mathrm{a}}$ & $38.8^{\mathrm{bcd}}$ & $41.8^{\mathrm{ab}}$ & $40.6^{\mathrm{ab}}$ & $37.4^{\mathrm{cd}}$ & $33.3^{\mathrm{ef}}$ & $35.9^{\mathrm{de}}$ & $32.6^{\mathrm{f}}$ \\
\hline PWP Vol. \% & $20.6^{\mathrm{ab}}$ & $18.8^{\mathrm{b}}$ & $21.4^{\mathrm{a}}$ & $18.7^{\mathrm{bc}}$ & $19.4^{\mathrm{ab}}$ & $18.8^{\mathrm{b}}$ & $16.1^{\mathrm{de}}$ & $16.6^{\mathrm{cd}}$ & $14.50^{\mathrm{e}}$ \\
\hline $\operatorname{SMBC}(\mu \mathrm{g} / \mathrm{g})$ & $796.8^{\mathrm{a}}$ & $701.4^{c}$ & $747.7^{\mathrm{b}}$ & $725.6^{\mathrm{bc}}$ & $641.0^{\mathrm{d}}$ & $609.9^{\mathrm{d}}$ & $421.8^{\mathrm{f}}$ & $528.6^{\mathrm{e}}$ & $519.1^{\mathrm{e}}$ \\
\hline DHA $(\mu \mathrm{g} / \mathrm{g} / \mathrm{hr})$ & $0.380^{\mathrm{a}}$ & $0.277^{\mathrm{cd}}$ & $0.305^{\mathrm{bc}}$ & $0.402^{\mathrm{a}}$ & $0.321^{\mathrm{b}}$ & $0.288^{\mathrm{bcd}}$ & $0.198^{\mathrm{e}}$ & $0.245^{\mathrm{d}}$ & $0.287^{\mathrm{cd}}$ \\
\hline $\mathrm{BR}(\mu \mathrm{g} \mathrm{CO} 2 / \mathrm{g} \mathrm{DW} / \mathrm{hr})$ & $0.367^{\mathrm{c}}$ & $0.307^{\mathrm{d}}$ & $0.376^{\mathrm{c}}$ & $0.517^{\mathrm{a}}$ & $0.422^{\mathrm{b}}$ & $0.311^{\mathrm{d}}$ & $0.221^{\mathrm{e}}$ & $0.298^{\mathrm{d}}$ & $0.316^{\mathrm{d}}$ \\
\hline $\begin{array}{c}\text { Phosphatase }(\mu \mathrm{g} p- \\
\text { nitrophenol/g dry } \\
\text { soil/h) }\end{array}$ & $240.95^{\mathrm{ab}}$ & $195.30^{c}$ & $254.04^{\mathrm{a}}$ & $250.46^{\mathrm{a}}$ & $240.90^{\mathrm{ab}}$ & $184.90^{c}$ & $116.22^{d}$ & $183.10^{c}$ & $221.43^{b}$ \\
\hline Sand $(\%)$ & $44.7^{\mathrm{d}}$ & $40.6^{\mathrm{e}}$ & $40.4^{\mathrm{e}}$ & $45.9^{\mathrm{d}}$ & $39.4^{\mathrm{e}}$ & $41.6^{\mathrm{e}}$ & $72.5^{\mathrm{a}}$ & $63.2^{\mathrm{b}}$ & $49.9^{c}$ \\
\hline Silt (\%) & $20.0^{c}$ & $20.9^{\mathrm{ab}}$ & $21.5^{\mathrm{ab}}$ & $18.4^{\mathrm{c}}$ & $21.3^{\mathrm{ab}}$ & $22.7^{\mathrm{a}}$ & $11.6^{\mathrm{d}}$ & $8.6^{\mathrm{e}}$ & $17.6^{\mathrm{c}}$ \\
\hline Clay $(\%)$ & $35.3^{\mathrm{b}}$ & $38.5^{\mathrm{a}}$ & $38.1^{\mathrm{a}}$ & $35.7^{\mathrm{b}}$ & $39.3^{\mathrm{a}}$ & $35.7^{\mathrm{b}}$ & $15.9^{\mathrm{e}}$ & $27.6^{\mathrm{d}}$ & $32.5^{\mathrm{c}}$ \\
\hline Sand:(silt + clay) & $0.81^{\mathrm{de}}$ & $0.68^{\mathrm{de}}$ & $0.68^{\mathrm{de}}$ & $0.85^{\mathrm{dc}}$ & $0.66^{\mathrm{e}}$ & $0.71^{\mathrm{de}}$ & $2.65^{\mathrm{a}}$ & $1.77^{\mathrm{b}}$ & $1.00^{\mathrm{c}}$ \\
\hline Silt: clay & $0.57^{\mathrm{bc}}$ & $0.54^{\mathrm{bc}}$ & $0.57^{\mathrm{bc}}$ & $0.52^{\mathrm{c}}$ & $0.54^{\mathrm{c}}$ & $0.64^{\mathrm{b}}$ & $0.74^{\mathrm{a}}$ & $0.31^{\mathrm{d}}$ & $0.54^{\mathrm{c}}$ \\
\hline
\end{tabular}

Table 2: Association of different soil parameters across all the Land use practices estimated through Person's correlation coefficient

\begin{tabular}{|c|c|c|c|c|c|c|c|c|c|c|c|c|c|c|c|c|c|c|c|c|c|c|c|}
\hline & Sand & Silt & Clay & Sand: silt +clay & BD & MWD & DR & IR & WHC & ER & FC & PWP & PWA & pH & Al & Ca + Mg & SOC & $\mathbf{N}$ & $\mathbf{P}$ & $\mathbf{K}$ & $\mathbf{S}$ & SMBC DHA & BR PA \\
\hline Sand & 1 & & & & & & & & & & & & & & & & & & & & & & \\
\hline Silt & -0.90 & 1 & & & & & & & & & & & & & & & & & & & & & \\
\hline Clay & -0.96 & 0.73 & 1 & & & & & & & & & & & & & & & & & & & & \\
\hline Sand: silt +clay & 0.98 & -0.82 & -0.97 & 1 & & & & & & & & & & & & & & & & & & & \\
\hline BD & 0.09 & 0.02 & -0.15 & 0.13 & 1 & & & & & & & & & & & & & & & & & & \\
\hline MWD & -0.53 & 0.45 & 0.54 & -0.54 & -0.21 & 1 & & & & & & & & & & & & & & & & & \\
\hline DR & 0.56 & -0.42 & -0.59 & 0.55 & 0.40 & -0.40 & 1 & & & & & & & & & & & & & & & & \\
\hline IR & -0.17 & 0.08 & 0.21 & -0.25 & 0.11 & \begin{tabular}{|l|l|}
0.24 \\
\end{tabular} & 0.32 & 1 & & & & & & & & & & & & & & & \\
\hline WHC & -0.69 & 0.48 & 0.74 & -0.68 & -0.31 & 0.45 & -0.77 & -0.06 & 1 & & & & & & & & & & & & & & \\
\hline ER & \begin{tabular}{|l|l}
0.89 \\
\end{tabular} & -0.67 & -0.93 & 0.91 & 0.31 & \begin{tabular}{|c|}
-0.55 \\
\end{tabular} & 0.68 & -0.15 & $5-0.76$ & 1 & & & & & & & & & & & & & \\
\hline $\mathrm{FC}$ & -0.63 & 0.49 & 0.65 & -0.61 & 0.06 & 0.55 & -0.44 & -0.01 & 0.43 & -0.63 & 1 & & & & & & & & & & & & \\
\hline PWP & -0.52 & 0.48 & 0.49 & -0.54 & 0.08 & \begin{tabular}{|l|}
0.32 \\
\end{tabular} & -0.05 & 0.62 & 0.22 & -0.45 & 0.14 & 1 & & & & & & & & & & & \\
\hline PWA & -0.31 & 0.16 & 0.37 & -0.27 & -0.14 & \begin{tabular}{|l|l|}
0.15 \\
\end{tabular} & -0.54 & -0.46 & 50.47 & -0.36 & 0.55 & -0.26 & 1 & & & & & & & & & & \\
\hline $\mathrm{pH}$ & -0.38 & 0.21 & 0.44 & -0.43 & 0.00 & \begin{tabular}{|l|}
0.35 \\
\end{tabular} & -0.17 & 0.46 & 0.28 & -0.44 & 0.13 & 0.59 & -0.25 & 1 & & & & & & & & & \\
\hline $\mathrm{Al}$ & 0.06 & -0.15 & 0.01 & -0.03 & 0.26 & \begin{tabular}{|l|}
-0.14 \\
\end{tabular} & 0.32 & 0.35 & -0.16 & 0.04 & 0.12 & 0.07 & 0.11 & -0.25 & 1 & & & & & & & & \\
\hline $\mathrm{Ca} \_\mathrm{Mg}$ & -0.31 & 0.26 & 0.31 & -0.32 & 0.04 & \begin{tabular}{|l|}
0.43 \\
\end{tabular} & -0.19 & 0.27 & 0.20 & -0.32 & 0.18 & 0.41 & -0.15 & 0.79 & -0.37 & 1 & & & & & & & \\
\hline SOC & \begin{tabular}{|c|} 
\\
\end{tabular} & 0.18 & 0.26 & -0.27 & -0.33 & \begin{tabular}{|l|} 
\\
\end{tabular} & -0.20 & 0.22 & 0.26 & -0.32 & 0.32 & 0.30 & \begin{tabular}{|l|} 
\\
\end{tabular} & 0.09 & -0.06 & 0.18 & 1 & & & & & & \\
\hline $\mathrm{N}$ & \begin{tabular}{|c|}
-0.65 \\
\end{tabular} & 0.44 & 0.71 & -0.63 & -0.30 & \begin{tabular}{|l|}
0.31 \\
\end{tabular} & -0.71 & -0.12 & 20.76 & $\mid-0.74$ & 0.53 & \begin{tabular}{|l|l|}
0.13 \\
\end{tabular} & 0.55 & 0.12 & -0.16 & 0.08 & 0.28 & 1 & & & & & \\
\hline
\end{tabular}




\begin{tabular}{|c|c|c|c|c|c|c|c|c|c|c|c|c|c|c|c|c|c|c|c|c|c|c|c|}
\hline $\mathrm{P}$ & -0.52 & 0.37 & 0.56 & -0.51 & $\mid-0.11$ & 0.08 & -0.53 & -0.10 & 0.51 & $\mid-0.54$ & 0.49 & 0.11 & 0.52 & 0.03 & 0.05 & 0.12 & \begin{tabular}{|l|l|l|}
0.10 & 0.68 & 1 \\
\end{tabular} & & & & & & \\
\hline $\mathrm{K}$ & -0.51 & 0.29 & 0.59 & -0.55 & -0.20 & 0.41 & -0.55 & 0.10 & 0.60 & -0.63 & 0.48 & 0.36 & 0.31 & 0.38 & -0.12 & 0.38 & \begin{tabular}{|l|l|l|}
0.46 & 0.68 & 0.58 \\
\end{tabular} & 1 & & & & & \\
\hline $\mathrm{S}$ & -0.01 & -0.05 & 0.05 & -0.04 & -0.35 & -0.25 & $\mid-0.47$ & -0.55 & 0.31 & -0.17 & -0.06 & -0.36 & 0.29 & -0.18 & -0.21 & -0.31 & $-0.27|0.26| 0.17$ & -0.04 & 1 & & & & \\
\hline SMBC & -0.76 & 0.62 & 0.76 & -0.76 & -0.29 & 0.62 & -0.61 & 0.16 & 0.63 & -0.77 & 0.65 & 0.37 & 0.43 & 0.25 & \begin{tabular}{|l|}
-0.15 \\
\end{tabular} & 0.30 & \begin{tabular}{|l|l|l|}
0.54 & 0.69 & 0.55 \\
\end{tabular} & 0.74 & -0.07 & 1 & & & \\
\hline DHA & -0.60 & 0.46 & 0.63 & -0.65 & -0.21 & 0.39 & -0.47 & 0.21 & 0.54 & -0.62 & 0.53 & 0.36 & 0.31 & 0.15 & 0.11 & 0.18 & \begin{tabular}{|l|l|l|}
0.57 & 0.60 & 0.60 \\
\end{tabular} & 0.67 & 0.05 & 0.79 & 1 & & \\
\hline BR & -0.55 & 0.38 & 0.60 & -0.58 & -0.15 & 0.28 & -0.62 & -0.02 & 0.68 & -0.63 & 0.52 & 0.29 & 0.40 & 0.33 & -0.04 & 0.39 & \begin{tabular}{|l|l|l|}
0.36 & 0.65 & 0.68 \\
\end{tabular} & 0.71 & 0.21 & 0.62 & 0.78 & 1 & \\
\hline PA & $\mid-0.69$ & 0.48 & 0.74 & -0.73 & -0.09 & 0.44 & $\mid-0.39$ & 0.45 & 0.55 & -0.74 & 0.56 & 0.55 & 0.16 & 0.54 & -0.02 & 0.50 & \begin{tabular}{|l|l|l|l|l|}
0.36 & 0.60 & 0.55 \\
\end{tabular} & 0.69 & -0.07 & 0.72 & 0.71 & 0.71 & 1 \\
\hline
\end{tabular}

BD-Bulk density, HC-Hydraulic conductivity, MWD- Mean weight diameter, DR-Dispersion ratio, IR-Infiltration rate, WHC-Water holding capacity, ER-Erosion ratio, FC-Field capacity, PWP-Permanent wilting point, PAW-Plant available water, Al-Exchangeable Aluminium, SOC-

Soil organic carbon, N-Available Nitrogen, P-Available Phosphorus, K-Available Potassium, S-Available Sulphur, SMBC-Soil microbial biomass carbon, DHA-Dehydrogenase activity, BR-Basal respiration, PA- Phosphatase activity.

* ' $r$ ' values more than 0.29 are significant at 5\% level of significant, $n=45$;

Table 3: Identification of most sensitive soil health attributes through PCA analysis

\begin{tabular}{|c|c|c|c|c|c|c|c|}
\hline Principal components & PC1 & PC2 & PC3 & PC4 & PC5 & PC6 & Communality \\
\hline Eigen value & 11.677 & 3.479 & 2.069 & 1.915 & 1.428 & 1.210 & \\
\hline Percent & 43.247 & 12.885 & 7.663 & 7.093 & 5.288 & 4.483 & \\
\hline Cumulative percent & 43.247 & 56.131 & 63.794 & 70.887 & 76.175 & 80.658 & \\
\hline \multicolumn{8}{|l|}{ Eigen vectors } \\
\hline Sand & -.945 & -.208 & -.027 & -.058 & -.101 & -.146 & 0.981 \\
\hline Silt & .845 & .110 & .046 & .042 & .023 & .067 & 0.971 \\
\hline Clay & .903 & .254 & .015 & .063 & .146 & .177 & 0.964 \\
\hline Sand: silt +clay & -.933 & -.247 & -.023 & -.091 & -.113 & -.099 & 0.965 \\
\hline Silt: clay & -.027 & -.147 & .080 & -.031 & -.098 & -.088 & 0.940 \\
\hline Bulk Density & -.084 & .056 & .631 & -.536 & -.029 & .045 & 0.762 \\
\hline Hydraulic Conductivity & .041 & .001 & .195 & -.007 & .053 & -.137 & 0.672 \\
\hline Mean Weight Diameter & .512 & -.140 & .107 & .509 & .497 & .212 & 0.794 \\
\hline Dispersion Ratio & -.495 & -.310 & .538 & -.144 & -.223 & -.248 & 0.814 \\
\hline Infiltration Rate & .236 & .026 & .581 & .183 & .117 & -.418 & 0.888 \\
\hline Max. WHC & .661 & .339 & -.331 & .138 & .156 & .116 & 0.760 \\
\hline Erosion Ratio & -.850 & -.262 & .139 & -.154 & -.189 & -.150 & 0.937 \\
\hline Field capacity & .432 & .202 & -.058 & .244 & .097 & .727 & 0.778 \\
\hline Permanent Wilting Point & .462 & .232 & -.114 & .403 & .070 & -.025 & 0.717 \\
\hline Plant Water Available & .253 & .226 & -.017 & -.025 & -.103 & .816 & 0.810 \\
\hline $\mathrm{pH}$ & .367 & .140 & $\begin{array}{l}.017 \\
-.099\end{array}$ & .005 & .788 & -.128 & 0.886 \\
\hline Ex. $\mathrm{Al}^{3+}$ & .115 & .085 & .570 & -.003 & -.299 & .136 & 0.894 \\
\hline $\mathrm{Ca}^{2+}+\mathrm{Mg}^{2+}$ & .151 & .404 & .340 & .159 & .688 & .014 & 0.808 \\
\hline SOC & .106 & .255 & .125 & .868 & .061 & .037 & 0.837 \\
\hline Available N & .564 & .461 & -.223 & .108 & .003 & .240 & 0.793 \\
\hline Available P & .341 & .701 & -.077 & -.115 & -.071 & .365 & 0.777 \\
\hline Available K & .345 & .628 & .069 & .291 & .320 & .080 & 0.822 \\
\hline Available S & .078 & .119 & -.863 & -.227 & -.204 & .010 & 0.829 \\
\hline SMBC & .619 & .392 & .018 & .449 & .188 & .248 & 0.883 \\
\hline Dehydrogenase activity & .446 & .702 & -.014 & .434 & -.024 & .092 & 0.864 \\
\hline Basal Respiration & .357 & .804 & -.193 & .130 & .244 & .166 & 0.866 \\
\hline Phosphatase activity & .569 & .566 & .147 & .130 & .320 & .005 & 0.860 \\
\hline
\end{tabular}

Table 4: Weights assigned to sensitive indicators

\begin{tabular}{|c|c|c|c|c|c|}
\hline Sand\% & BR & Av. S & SOC (\%) & pH & PAW \\
\hline 0.185877 & 0.158143 & 0.16974823 & 0.17073171 & 0.15499607 & 0.160504 \\
\hline
\end{tabular}

Table 5: Soil quality index (SQI) under different Land use systems

\begin{tabular}{|c|c|}
\hline Land use & Soil Quality Index (SQI) \\
\hline Alder + Tea +Black Pepper & $0.758^{\mathrm{b}^{*}}$ \\
\hline Silver oak +Pineapple & $0.732^{\mathrm{bc}}$ \\
\hline Som + Broom +Pineapple & $0.735^{\mathrm{bc}}$ \\
\hline Alder +Large cardamom & $0.858^{\mathrm{a}}$ \\
\hline Alder +Ginger & $0.756^{\mathrm{b}}$ \\
\hline Gumhar +Turmeric & $0.755^{\mathrm{b}}$ \\
\hline Jhum & $0.637^{\mathrm{d}}$ \\
\hline Agriculture (Maize) & $0.751^{\mathrm{b}}$ \\
\hline Pine forest & $0.705^{\mathrm{c}}$ \\
\hline
\end{tabular}

*Means in the column followed by common letters (a-c) are not statistically different at 5\% level of significance. 


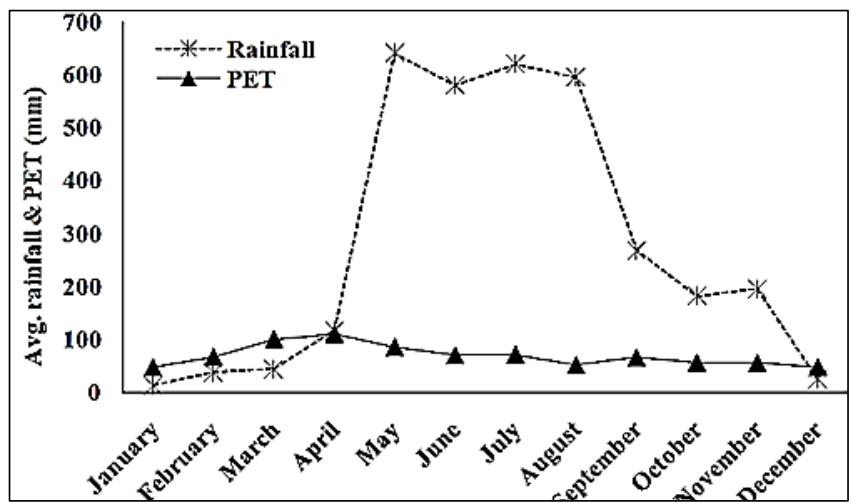

Fig 1: Long term average (28 years) of potential Evapotranspiration (PET) and Rainfall indicating deficit and surplus periods at the experimental site, Umiam, Meghalaya. (Source: Choudhury et al. 2012) [3]

\section{Conclusions}

This study of Land use impact on soil health showed that the practice of short cycle shifting cultivation (Jhum cultivation) has more degrading effect than the other forms of settled agricultural practiced on the slopping land (>40\% slope) of the north eastern hill region of India. Different physical, chemical and biological properties of the soil improved considerably under tree based Land use systems over a period of 25 years. The alder based AFPs with high nitrogen fixing capacity, were found to be the best Land use practice for improving the soil health which was reflected by better soil aggregation, water retention, nutrients availability and the higher soil quality index value. Since, the slopping land in the high rainfall $\mathrm{NEH}$ region are highly vulnerable to land degradation, alder based agroforestry system can be a sustainable system to protect the soil resources and at the same time sustain the production system for the resource poor hill people. In the settled terraced agriculture, appropriate conservation measures are required to be taken with respect to soil conservation, nutrient cycling, maintenance of soil organic matter and fertilizer management so that the soil health status does not deteriorate in long run.

\section{References}

1. Andrews SS, Karlen DL, Mitchell JP. A comparison of soil quality indexing methods for vegetable production systems in Northern California. Agriculture, ecosystems \& environment. 2002; 90(1):25-45.

2. Blake GR, Hartge KH. Bulk density. Methods of soil analysis: Part 1 Physical and mineralogical methods. 1986; 5:363-75.

3. Choudhury BU, Das A, Ngachan SV, Slong A, Bordoloi LJ, Chowdhury P. Trend analysis of long term weather variables in mid altitude Meghalaya, North-East India. Journal of Agricultural Physics. 2012; 12(1):12-22.

4. Choudhury BU, Fiyaz AR, Mohapatra KP, Ngachan S. Impact of Land uses, agrophysical variables and altitudinal gradient on soil organic carbon concentration of north- eastern Himalayan region of India. Land Degradation \& Development. 2016; 27(4):1163-74.

5. Datta M, Singh NP. Growth characteristics of multipurpose tree species, crop productivity and soil properties in agroforestry systems under subtropical humid climate in India. Journal of Forestry Research. 2007; 18(4):261-70.

6. Deb S, Tangjang S, Arunachalam A, Arunachalam K. Role of litter, fine roots and microbial biomass in soil $\mathrm{C}$ and $\mathrm{N}$ budget in traditionally managed agroforestry systems. Agroforestry in north east India: opportunities and challenges ICAR Research Complex for NEH Region, Umiam, Meghalaya. 2005:491-506.

7. Dhyani SK, Singh BP, Chauhan DS, Prasad RN. Evaluation of MPTS for Agroforestry system to ameliorate fertility of degraded acid alfisols on sloppy lands. Agroforestry systems for degraded lands. 1994; $1: 241-7$.

8. Dhyani SK, Tripathi RS. Biomass and production of fine and coarse roots of trees under agrisilvicultural practices in north-east India. Agroforestry systems. 2000; 50(2):107-21.

9. FAO. FAO Forestry Paper, FAO, Rome, 2006, 147.

10. Garcia-Gil JC, Plaza C, Soler-Rovira P, Polo A. Longterm effects of municipal solid waste compost application on soil enzyme activities and microbial biomass. Soil Biology and biochemistry. 2000; 32(13):1907-13.

11. Grewal SS, Abrol IP. Agroforestry on alkali soils: effect on some management practices on initial growth, biomass accumulation and chemical composition of selected tree species. Agroforestry systems. 1986; 4(3):221-32.

12. Gupta RP, Dakshinamoorthy C. Procedures for physical analysis of soil and collection of agro meteorological data. Indian Agricultural Research Institute, New Delhi. 1980, 293.

13. Jackson ML. Soil chemical analysis, pentice hall of India Pvt. Ltd., New Delhi, India, 1973.

14. Kafle G, Balla MK. Effectiveness of Root System of Grasses Used in Soil Conservation in Paundi Khola Sub Watershed of Lamjung District, Nepal. The Initiation. 2008; 2(1):121-9.

15. Karlen DL, Andrews SS, Weinh old BJ, Doran JW. Soil quality: Humankind's foundation for survival a research editorial by conservation professionals. Journal of Soil and Water Conservation. 2003; 58(4):171-9.

16. Kaur R, Singh O, Gurung HP. Soil erodibility indicestheir development, use and efficiency testing on Indian souls-a review. Indian Journal of Soil Conservation. 2003; 31(3):234-242.

17. Larson WE, Pierce FJ. Conservation and enhancement of soil quality. In Evaluation for sustainable land management in the developing world: proceedings of the International Workshop on Evaluation for Sustainable Land Management in the Developing World, Chiang Rai, Thailand, September. [Bangkok, Thailand: International Board for Soil Research and Management, 1991, 15-21

18. Lin C, Coleman NT. The Measurement of Exchangeable Aluminum in Soils and Clays 1. Soil Science Society of America Journal. 1960; 24(6):444-6.

19. Macfadyen A. Soil metabolism in relation to ecosystem energy flow and to primary and secondary production. In" Methods of Study in Soil Ecology" Proc. UNESCO/IBP Symp. Paris, 1967, 1970, 167-172.

20. Mandal D, Sharda VN. Appraisal of soil erosion risk in the Eastern Himalayan region of India for soil conservation planning. Land Degradation \& Development. 2013; 24(5):430-7.

21. Middleton HE. Properties of soils which influence soil erosion. US Dept. of Agriculture, 1930.

22. Nair PK, Kang BT, Kass DC. Nutrient cycling and soilerosion control in agroforestry systems. Agriculture and Environment: Bridging Food Production and Environmental Protection in Developing Countries. (Agriculture land). 117-38, 1995. 
23. Prasad RN. Degradation of soil and water resources visa-vis crop production problems in NEH region: a review. Indian Journal of Hill Farming. 1987; 1(1):1-8.

24. Saha R, Mishra VK. Long-term effect of various Land use systems on physical properties of silty clay loam soil of NE hills. Journal of the Indian Society of Soil Science. 2007; 55(2):112-8.

25. SAS Institute. SAS 9.2. SAS Institute, Cary, NC, 2010.

26. Schroth G, Lehmann J, Rodrigues MR, Barros E, Macêdo JL. Plant-soil interactions in multistrata agroforestry in the humid tropicsa. Agroforestry Systems. 2001; 53(2):85-102.

27. Sharma E. Nutrient dynamics in Himalayan alder plantations. Annals of Botany. 1993; 72(4):329-36.

28. Singh AK, Arunachalam A, Ngachan SV, Mohapatra KP, Dagar JC. From shifting cultivation to integrating farming: Experience of agroforestry development in the northeastern Himalayan region. In Agroforestry Systems in India: Livelihood Security \& Ecosystem Services Springer, New Delhi, 2014, 57-86.

29. Subbaiah BV. A rapid procedure for estimation of available nitrogen in soil. Curr. Sci. 1956; 25:259-60.

30. Tabatabai MA, Bremner JM. Use of p-nitrophenyl phosphate for assay of soil phosphatase activity. Soil biology and biochemistry. 1969; 1(4):301-7.

31. Tian H, Banger K, Bo T, Dadhwal VK. History of Land use in India during 1880-2010: Large-scale land transformations reconstructed from satellite data and historical archives. Global and Planetary Change. 2014; 121:78-88.

32. Tiwari BK, Shukla RP, Lynser MB, Tynsong H. Growth pattern, production, and marketing of Thysanolaena maxima (Roxb.) Kuntze: An important non-timber forest product of Meghalaya, India. Forests, Trees and Livelihoods. 2012; 21(3):176-87.

33. Vance ED, Brookes PC, Jenkinson DS. An extraction method for measuring soil microbial biomass C. Soil biology and Biochemistry. 1987; 19(6):703-7.

34. Vanlalhruaii R, Pandey HN, Barik SK, Tripathi RS, Prabhu SD. Changes in microbial biomass and activity in relation to shifting cultivation and horticultural practices in subtropical evergreen forest ecosystem of north-east India. Acta Oecologica. 2005; 28(2):163-72.

35. Walkley A, Black IA. An examination of the Degtjareff method for determining soil organic matter, and a proposed modification of the chromic acid titration method. Soil science. 1934; 37(1):29-38.

36. Wandermm, Bollero GA. Soil quality assessment of tillage impacts in Illinois. Soil Science Society of America Journal. 1999; 63(4):961-71.

37. Warkentin BP, Fletcher HF. Soil quality for intensive agriculture. In Proceedings of the International Seminar on Soil Environment and Fertility Management in Intensive Agriculture, 1977.

38. Wasteland Atlas of India.. Department of Land Resources, Government of India, http://dolr.nic.in/dolr/wasteland_atlas.asp, 2010.

39. Winkler N, Weymann W, Auge H, Klotz S, Finkenbein $\mathrm{P}$, Heilmeier H. Drought resistance of native pioneer species indicates potential suitability for restoration of post-mining areas. Web Ecology. 2015; 14(1):65-74.

40. Yoder RE. A direct method of aggregate analysis of soils and a study of the physical nature of erosion losses 1 . Agronomy Journal. 1936; 28(5):337-51.

41. Zhao WZ, Xiao HL, Liu ZM, Li J. Soil degradation and restoration as affected by Land use change in the semiarid Bashang area, northern China. Catena. Jan 15. 2005; 59(2):173-86. 